\title{
CULTURAL AND TOURISM DIVERSITY ON INSTAGRAM ACCOUNT OF BANDUNG CULTURAL AND TOURISM BOARD: A DISCOURSE ANALYSIS APPROACH
}

\author{
Rosaria Mita Amalia ${ }^{1}$ \\ ${ }^{1}$ Universitas Padjadjaran \\ rosaria.mita.amalia@unpad.ac.id
}

\begin{abstract}
ABSTRAK
Keragaman budaya merupakan salah satu kekayaan bangsa yang bisa menjadi daya tarik wisata di suatu daerah. Kota Bandung sebagai ibu kota Provinsi Jawa Barat memiliki potensi dan daya tarik pariwisata sehingga dapat menarik wisatawan untuk datang. Dinas Kebudayaan Kota Bandung merupakan salah satu kantor yang memaksimalkan akun Instagram resmi mereka @ disbudpar.bdg sebagai media untuk mempromosikan berbagai tempat wisata dan keragaman budaya sebagai salah satu daya tarik Kota Bandung bagi wisatawan. Konten promosi yang ditampilkan di feed akun Instagram mewakili keragaman budaya dan pariwisata Kota Bandung. Berbagai potensi dan atraksi budaya ditampilkan dalam gambar visual dan narasi yang menawan. Studi sebelumnya berfokus pada nilai potensial Instagram untuk mempromosikan situs pariwisata di Indonesia, terutama di Malang dan Bali, dan menggambarkan bagaimana Instagram menciptakan tujuan merek melalui sisi fotografi. Studi ini menganalisis topik yang disajikan dan instrumen linguistik yang digunakan sebagai penanda keragaman budaya dan pariwisata dalam konten ini. Analisis ini menggunakan teori Analisis Wacana Kritis Fairclough (1995) mengenai analisis teks dan metode penelitian bersifat deskriptif kuantitatif. Topik yang ditampilkan seperti tempat wisata, atraksi seni, penggunaan bahasa Sunda, wisata kuliner, dll menunjukkan berbagai budaya dan seni dari kota Bandung. Hasil analisis menunjukkan bahwa ada 11 klasifikasi topik mengenai keragaman budaya dan pariwisata yaitu
\end{abstract}

Kata kunci: budaya; pariwisata; keragaman; analisis wacana

\begin{abstract}
Cultural diversity is one of the nation's wealth that can be a tourist attraction in an area. The city of Bandung as the capital city of West Java Province has the potential and allure of tourism so that it can attract tourists to come. The Bandung City Tourism Culture Office is one of the offices that maximizes their official Instagram account @ disbudpar.bdg as a medium for promoting various tourist attractions and cultural diversity as one of the attractions of Bandung for tourists. The promotional content displayed in the Instagram account feeds represents the cultural and tourism diversity of Bandung city. Various potentials and cultural attractions are displayed in visual images and captivating narratives. The previous studies focuses on the potential value of Instagram for promoting tourism site in Indonesia, especially in Malang and Bali, and describing how Instagram creating brand destination through photography side.This study analyzes the topics presented and the linguistic instruments used as markers of cultural diversity and tourism in these contents. The analysis uses Fairclough's Critical Discourse Analysis (1995) theory regarding text analysis and the research method is descriptive quantitative. Topics that are displayed such as tourist attractions, art attractions, the use of Sundanese language, culinary tours, etc. show the various cultures and arts from the city of Bandung. The results of the analysis show that there are 11 classification of topics regarding cultural diversity and tourism namely
\end{abstract}

Keywords: culture; tourism; diversity; discourse analysis 
Prosiding The 1st National Conference on Applied Business, Education, \& Technology (NCABET)", Unversitas Bina Bangsa 2021

DOI Article : 10.46306/ncabet.v1i1.56

\section{INTRODUCTION}

Indonesia is one of the countries located on the Asian continent, more precisely in the Southeast Asia region and has more than 17,000 islands scattered in its territory. Indonesia is known as an archipelago and consists of $2 / 3$ of the ocean area so that it is also known as one of the maritime countries in the world. Each island has different customs, values, and habits. The customs, values and habits are intangible wealth for people in Indonesia. From 17,054 islands that make up the Indonesian archipelago, there is the island of Java which is known for its unique history and its beauty. West Java Province is one of the provinces that attract attention, besides having a dense population, the province has a moderate climate and extraordinary natural wealth (Amalia, 2017). The city of Bandung is one of the most beautiful cities in West Java Province and it is the capital of this province which is full of tourism attractions. Tourism is another economic driver in the city of Bandung besides business, creative industry, hightech and manufacturing industries.

Bandung city is a popular weekend destination for residents of Jakarta because it is located about 180 kilometres southeast of Jakarta, the metropolitan and capital city on Indonesia. During the colonial Dutch East Indies period, Bandung is well-known as Paris van Java because it's beauty. Bandung is also known aboard as host city for the first Asian-African Conference in 1955 . The conference was attended by the heads of states representing twentynine independent countries from Asia and Africa and hosted by President Soekarno, the first President of Indonesia. The conference was held at the Gedung Merdeka (Merdeka Building) in Asia-Africa Street and it is currently one of the historic places of pride of residents in West Java and as a historical tourist spot frequently visited by domestic and foreign tourists. Gedung Merdeka in Asia-Africa Street and is currently one of the historical places of pride of residents in West Java and as a historical tourist spot frequently visited by domestic and foreign tourists.

In addition to the website https://www.disbudpar.bandung.go.id/, the readers may also follow various information regarding tourist activities in the city of Bandung through social media Instagram @disbudpar.bdg (https://www.instagram.com/disbudpar.bdg/?hl= en.). Along with the development of digital information technology and the ease of accessing information in the digital world, government units such as the Bandung City Culture and Tourism Office also take advantage of various social media as a medium for disseminating information related to culture and tourism.

In this study, the social media used as data is official Instagram account. Instagram which was launched on October 6, 2010 is a type of social media such as Facebook, Pinterest, Twitter, Linkedin etc. Instagram is a social media that combines text, audio and video 
messages sent via internet platforms that can be quickly accepted by audiences and they can actively participate in both creating messages and responding to existing messages. The following can be seen an Instagram definition quote from the page,

There are some researchers doing their study on instagram and tourism. Fatanti and Suyadnya (2015) on their article titled 'Beyond User Gaze: How Instagram Creates Tourism Destination Brand?' published at Procedia - Social and Behavioral Sciences focus on how Instagram becomes a popular media to promote tourism site in Indonesia. They describe the potential value of Instagram for promoting tourism site in Indonesia, especially in Malang and Bali, and describing how Instagram creating brand destination through photography side. Users based social media or User Generated Content (UGC) provides a convenience access to user to access information and also disseminate it to public. They conclude that UGC through social media helps promoting awareness and creates interest towards a product and destination. Another related article written by Yu and Sun (2019) 'The Role of Instagram in the UNESCO's Creativity City of Gastronomy: A Case Study of Macau' published in Tourism Management uses quantitative content analysis on Instagram to explore the most popular cuisine. They mention that instagram has an important role to preserve and revive Macau culture of gastronomy. The findings indicated that Taiwanese cuisine, food from local café, and local snacks are the most popular ones.

This paper is a preliminary research paper concerning the cultural diversity displayed in instagram account of Bandung Cultural and Tourism Board. It discusses the content and meaning of cultural and tourism diversity in instagram account through discourse analysis approach. This approach provides instruments or tools that can show the topics discussed on data. Using linguistic instrument on textual analysis such as visual signs and verbal signs such as lexical style, topic choice, structure of the sentence, the researchers have a purpose to show the readers the diversity of culture and tourism in instagram account.

\section{Related Literature Three Dimension Model of Fairclough}

In analyzing data in the form of information related to cultural diversity and tourism in the city of Bandung on feeds on the official Instagram account @ disbudpar.bdg, the authors use the theory of Fairclough (1995) regarding critical discourse analysis (CDA). Critical Discourse Analysis (CDA) is an understanding of discourse that is not merely positioned as the object of language study, which is an understanding of traditional linguistics, but in the context of language as a tool used for certain purposes and practices, including the practice of ideology. Quoting the statement from Fairclough which states that (1995: 2), "CDA is consolidated here as a 'three-dimensional' framework where the aim is to map three separates 
Prosiding The 1st National Conference on Applied Business, Education, \& Technology (NCABET)"

Unversitas Bina Bangsa 2021

DOI Article : 10.46306/ncabet.v1i1.56

forms of analysis of discourse practice (spoken or written) language text, analysis of discourse practice (processes of text production, distribution and consumption) and analysis of discursive events as instances of sociocultural practice".

The Critical Discourse Analysis (CDA) model by Fairclough (2001) differentiates the analysis into textual analysis and socio-cultural analysis. The textual analysis aims to give excellent insights about what is in the text, while the sociocultural analysis provides perspectives that are not expressed in the text. He further mentions that sociocultural analysis has various orientations such as economic, political, and cultural aspects that are possible to be simplified in discourse. To apply the CDA model by Fairclough (2001), three interrelated processes of analysis that are connected to three inter-related dimensions of discourse should be performed. Since the authors only focus on instrument linguistics as text analysis, so two others aspects will not be discussed on this paper. The three dimensions can be seen in the following figure.

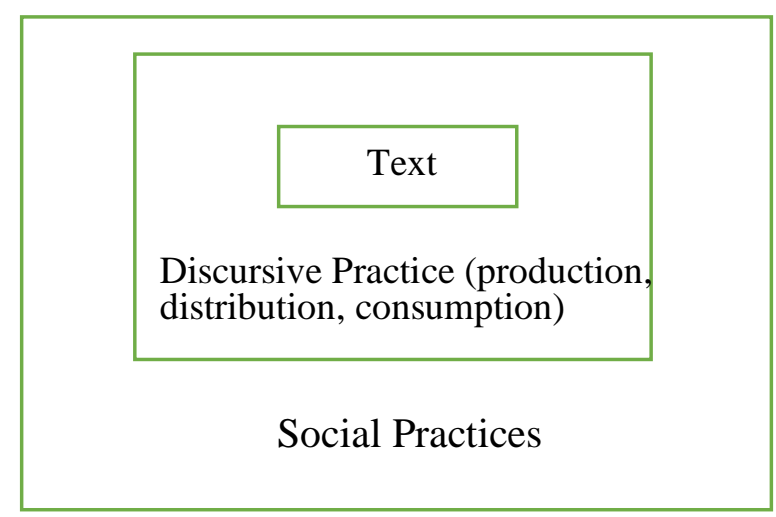

Figure 1. Three-dimensional Model of Fairclough

\section{Instagram Account on Bandung City Culture and Tourism Office}

The Bandung City Culture and Tourism Office (Disbudpar) has an official social media account Instagram @ disbudpar.bdg as a medium for disseminating information about various tourism and culture-related programs in Bandung city. Instagram account was set in June, 2015 and until this month (September 2020), this account has published 1678 feeds. Various information related to tourism and cultural attractions held in the city of Bandung can be seen by the followers of this account, which reached 44,700 followers.

\section{METHOD}

This study intended to answer the following questions: (1) What are topics found on official instagram account of Disbudpar kota Bandung focusing on cultural and tourism 
diversity? (2) What are Linguistic instruments found as markers for cultural and tourism diversity?. To answer these questions, this study further employed a descriptive qualitative approach. According to Creswell (2014), a descriptive qualitative method aimed to describe the phenomenon found in an everyday situation, in this context, the phenomenon is the information on official instagram account @ disbudpar.bdg.

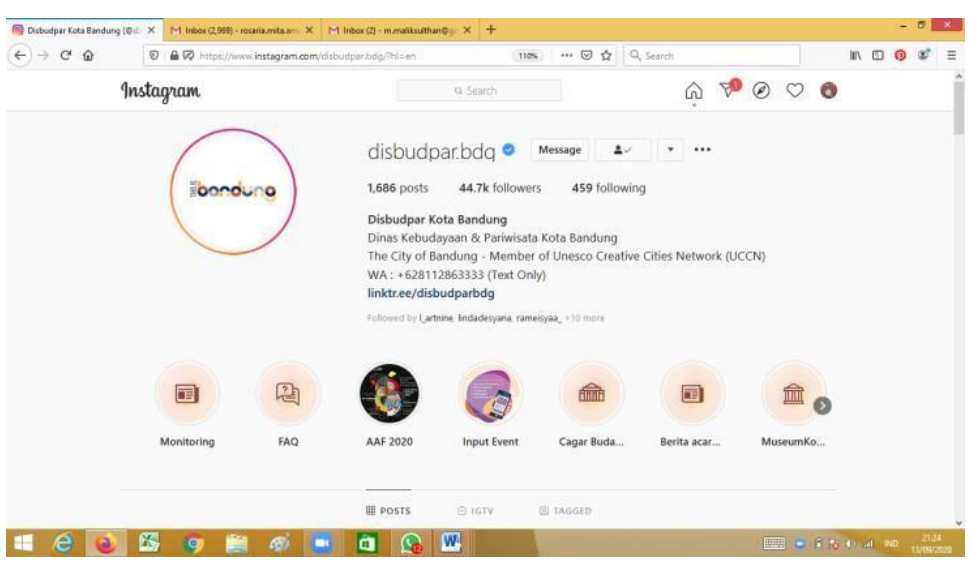

Picture 1. Official Instagram Account @ disbudpar.bdg

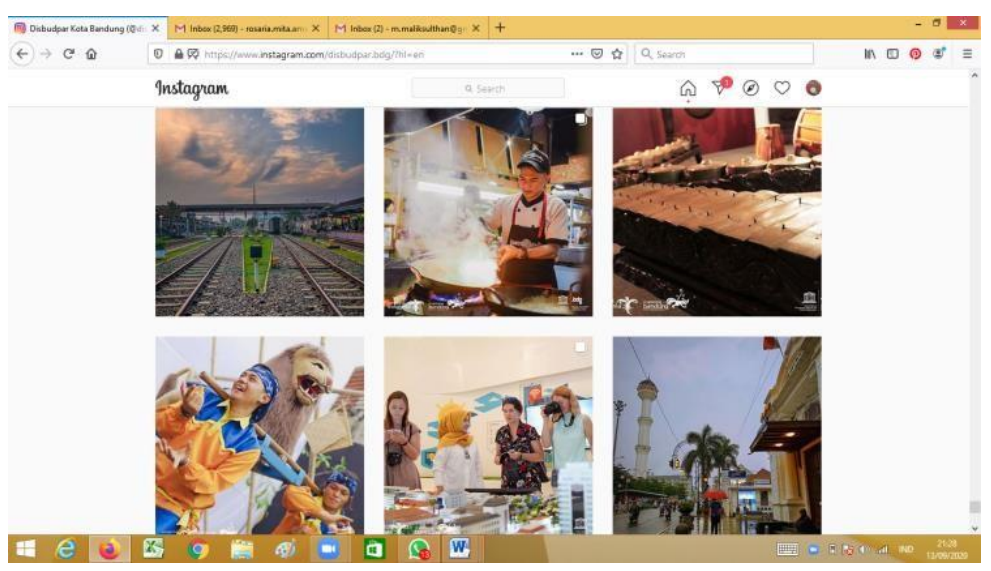

Picture 2. Feeds on Instagram Account

\section{Result and Discussion 1. Topics of the Feeds on Instagram Account}

The word 'cultural (adjective)' can be defined ' relating to the habits, traditions, and beliefs of a society'. The word 'culture (noun)' based on cambridge dictionary means the way of life, especially the general customs and beliefs, of a particular group of people at a particular time (https://dictionary.cambridge.org/dictionary/english/cultural). The definition of culture has been stated by Koentjaraningrat (2002: 203) which refers to the whole system of ideas, actions, and results of human work in life. According to Harsya Bachtiar (1976: 11) culture is elements that include beliefs, knowledge possessed by the community, the language used, the values applied in society and the regulations that apply in it. In addition to providing a definition of culture, Koentjaraningrat, (2002: 203-204) also stated seven (7) cultural elements that are 
Prosiding The 1st National Conference on Applied Business, Education, \& Technology (NCABET)",

Unversitas Bina Bangsa 2021

DOI Article : 10.46306/ncabet.v1i1.56

universal, namely language, knowledge systems, social systems or social organizations, systems of living equipment and technology, systems of livelihoods, religious system, and art. All of these cultural elements can be found and developed in society. Standing on the above mentioned coverage, the intangible heritage originates from local cultures in this Nusantara or archipelago, including: tradition, folklore and legend, mother tongue, oral history, creativity (dances, songs, drama shows), adaptability and the uniqueness of the local community (Galla, 2001, p. 12) (in Amalia et all., 2020: 14408).

For this research, there is another keyword that is tourism whose meaning is the business of providing services such as transport, places to stay or entertainment for people who are on holiday (https://dictionary.cambridge.org/dictionary/english/tourism). Cultural and tourism diversity in this study refer to the diversity of cultural elements such as language, art, values, food tastes as well as tourist destinations, both natural and artificial tourism and other things related to culture and attracting tourists.

There are 76 data on instagram feeds regarding to tourist attraction in Bandung. On this topic, the Bandung City government is very active through its Instagram account, promoting various tourist attractions in the city. Tourist attractions can be in the form of natural attractions such as Dago Forest Park (Taman Hutan Raya Dago), variety of public parks, Asia Africa building as landmark of the city, Trans Studio Bandung, Bandung Zoo, Saung Angklung Udjo, various tourist villages such as Kampung Wayang Urban, and various museums. The information wrapped in interesting pictures and clear information about the places.

The culinary data reaches 12 data. In this category, various famous and delicious culinary delights from the city of Bandung are also introduced such as tumpeng, various traditional snacks such as batagor, baso tahu, seblak, mie kocok etc., traditional foods with corn-based ingredients such as urab jagong, and various legendary culinary delights of Bandung. The information about culinary presented through clear storytelling such as ingredients, the taste, the reason for the meal to be favorite, the history and for some food/beverage the places they can be bought.

In an effort to introduce West Java arts and culture, the city government of Bandung holds various festivals and cultural arts performances. This activity is a medium for the introduction and preservation of various arts and traditional West Java culinary delights which are packaged in the form of festivals to attract local and foreign tourists to get to know various West-Java arts and cultures especially Bandung. The various festivals include Bandung Eid Festival, Bandung Lautan Angklung, Bandung Food Land, Asian African Carnival, Cultural \& Tourism Expo, Bandung International Art Festival, Bandung traditional dance festival, etc. 
West Java is famous for its rich cultural arts and attractive tourist attractions. This diversity is packaged in information contained in the Instagram feeds @ disbudpar.bdg such as information about the diversity of traditional Javanese-West musical instruments, one of which is the waditra saron. In addition, information on various types of dances that are very attractive is also displayed in the feeds, for example the Merak dance and the Jaipong dance. These dances are also a variety of traditional songs that are very beautiful to enjoy. Various information on the cultural and arts richness of West Java, especially the city of Bandung, has become a medium of information for the younger generation so that they can love traditional arts that involve many local wisdom.

The city of Bandung is known as the city of Paris van Java, means the city of Paris in Java because of its beauty. In several places, there are still many beautiful buildings from the Dutch colonial era which are still being preserved and become landmarks of the city, such as the Asia Africa Building, the Sate Building, the Bank Indonesia Building and many more. Various histories of these buildings along with photos of the buildings are interesting information from this Instagram account. From this information, we can get a variety of knowledge about the historical landmarks of the city of Bandung and other histories such as the Bandung Lautan Api incident.

The Instagram feeds also inform you about the uniqueness of the Bandung city icon. There is not plenty of data on this topic, but the information displayed regarding the uniqueness of Bandung city icons such as the Bandros vehicle, the Landmark Building and the Pasupati Bridge also adds to readers' insight as well as attracts tourists to visit.

The city of Bandung, which is the capital of the province of West Java, uses the Sundanese language everyday. Language which is part of the local culture is the strength of a society, because in language there are many cultural messages and local values that are very good and should be preserved, especially by the younger generation. On this topic, there are seven pieces of data that contain information about word guessing in Sundanese, word games, guessing expressions in Sundanese, information about the level of language, and so on.

Toponymy literally means place name. In linguistic theory, toponymy can be seen as a 'sign' that occurs not arbitrarily (Sobarna et.al., 2018: 149). In other words, toponymy discusses the history of the principle of naming a place or region. In Bandung city, there are many regional names that have interesting histories from the word of the city. This information really inspires readers and adds insight into the origin of regional naming in the city of Bandung. Among the toponymy displayed are Arcamanik toponymy, Pasir Kaliki toponymy, Buah Batu toponym and many more. There are 16 data for this information. From the information the 
Prosiding The 1st National Conference on Applied Business, Education, \& Technology (NCABET)"

Unversitas Bina Bangsa 2021

DOI Article : 10.46306/ncabet.v1i1.56

readers really get knowledge, something that they have not known before, how the specific name comes for specific places/areas.

Another topic is referring to the topic clusters that are not covered by the other topics above, including the diversity of holiday celebrations, lifestyle, the inauguration of buildings, the mayor's regulations regarding Covid-19 and others.

Table 1. Topics of the Feeds

\begin{tabular}{|c|c|c|c|}
\hline No. & Topics & $\begin{array}{c}\text { Numbers of } \\
\text { data }\end{array}$ & Percentage \\
\hline 1. & The diversity of tourist attractions in Bandung City. & 76 & $35.35 \%$ \\
\hline 2. & $\begin{array}{l}\text { The Diversity of various festival/event activities that } \\
\text { carry cultural diversity, especially Bandung city. }\end{array}$ & 48 & $22.35 \%$ \\
\hline 3. & $\begin{array}{l}\text { Information about the history of various buildings that } \\
\text { have become Bandung landmarks as tourist } \\
\text { destinations. }\end{array}$ & 19 & $8.84 \%$ \\
\hline 4. & $\begin{array}{l}\text { Other Topics (holiday celebrations, lifestyle, } \\
\text { inauguration of buildings, mayor regulations } \\
\text { regarding Covid-19, sad news, etc.) }\end{array}$ & 18 & $8.37 \%$ \\
\hline 5 . & $\begin{array}{l}\text { Origin of the word (Toponymy) various regions in } \\
\text { Bandung }\end{array}$ & 16 & $7.44 \%$ \\
\hline 6. & Variety of Bandung Culinary. & 12 & $5.58 \%$ \\
\hline 7. & Profile of Bandung city figures. & 12 & $5.58 \%$ \\
\hline 8. & Strengthening and Preserving Sundanese Language. & 7 & $3.25 \%$ \\
\hline 9. & Bandung's achievements in tourism. & 4 & $1.86 \%$ \\
\hline \multirow[t]{2}{*}{10.} & The uniqueness of Bandung city icons. & 3 & $1.4 \%$ \\
\hline & & 215 & $100 \%$ \\
\hline
\end{tabular}

The table above shows the order of the amount of data and the percentage related to the diversity of cultural and tourism topics. The dominant topic that arises is the diversity of types of tourist destinations in the city of Bandung, which are large in number and the tourist attractions are very diverse as much as $35.35 \%$. Then the second highest place is the diversity of various festivals / event activities that carry cultural diversity, especially Bandung city. 
Festival / event activities that cover culture, including angklung, traditional music, traditional dances, and traditional arts.

\section{Promotion and Preservation of Sundanese Language}

Data that contains information that can be categorized as a form of promotion as well as information on the wealth and diversity of culture is shown through data on Sundanese languange. The content which is packaged in the form of word guesses, word entries, then information about terms in Sundanese, information about the use of Sundanese language with pay attention to hearers (undak usuk basa), Sundanese poetry, various popular Sundanese song lyrics and many more.

The concept of persuasion is shown through word narrative which gives rise to the concept of guessing the word in Sundanese. Through this information, the city government of Bandung strives to preserve the Sundanese language through word plays. Instagram content is able to raise readers' curiosity about the use of the Sundanese language. As we know, language contains very high values and local wisdom which characterize the identity of its speakers.

The examples of the use of lexical choice in these data include the hashtag \# rebonyunda \# stunningbandung \# tourism \# wisatabandung \# wonderfulindonesia. Then the explanation on the data about the lyrics then uses a reminder such as, there are those who still remember the lyrics of this song, the lyrics of this song are indeed the easiest to memorize. Indirectly, this sentence invites readers to recall the lyrics that are considered popular among the people of Bandung.

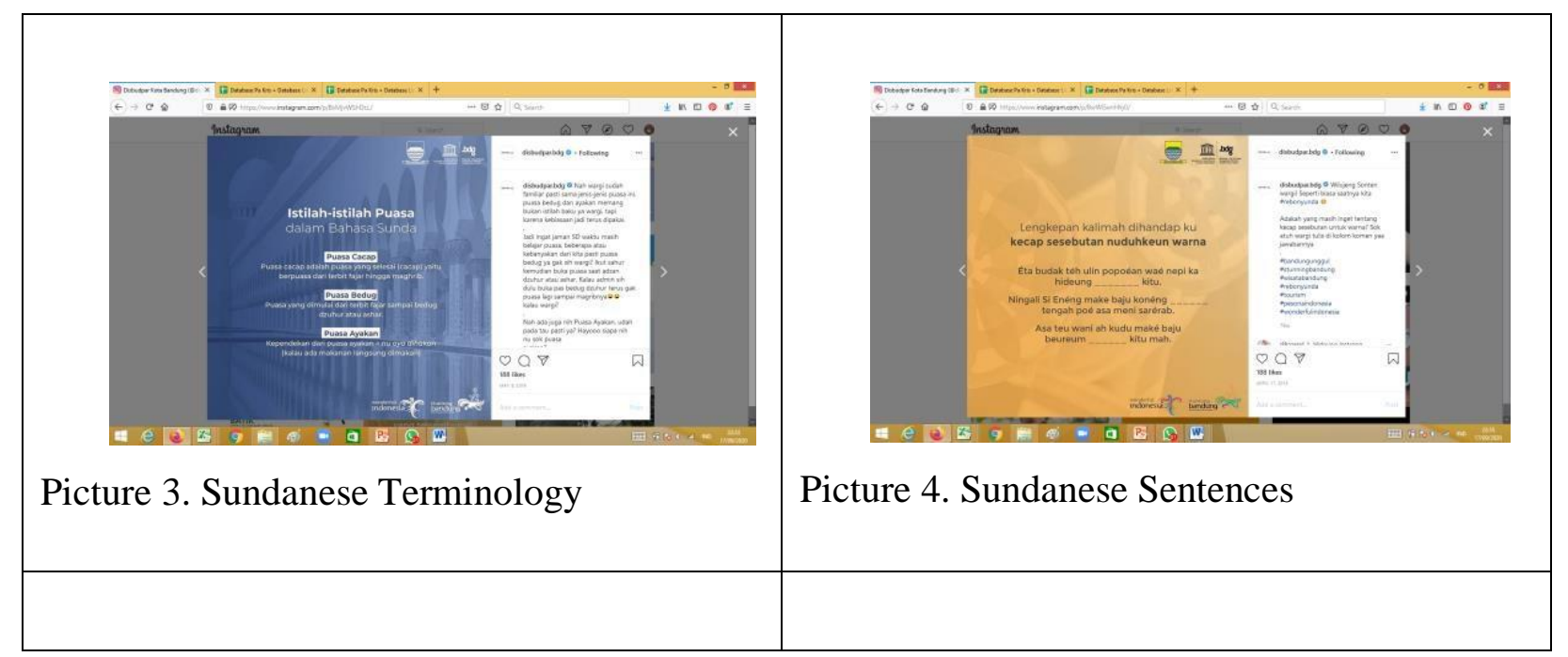


Prosiding The 1st National Conference on Applied Business, Education, \& Technology (NCABET)", Unversitas Bina Bangsa 2021

DOI Article : 10.46306/ncabet.v1i1.56

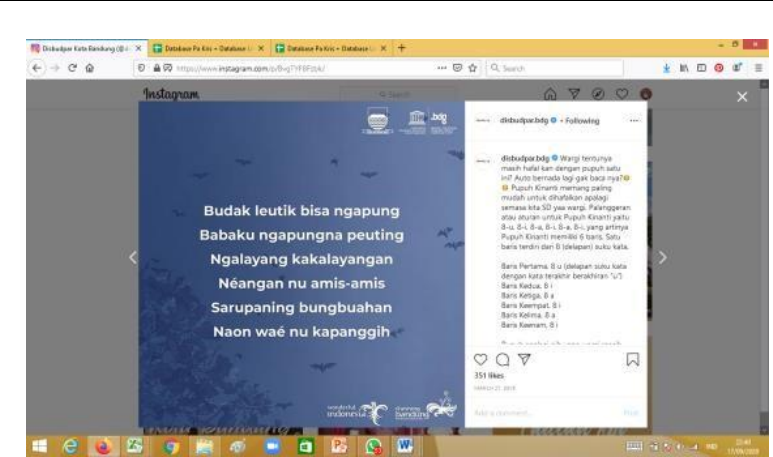

Picture 5. Sundanese Poetry

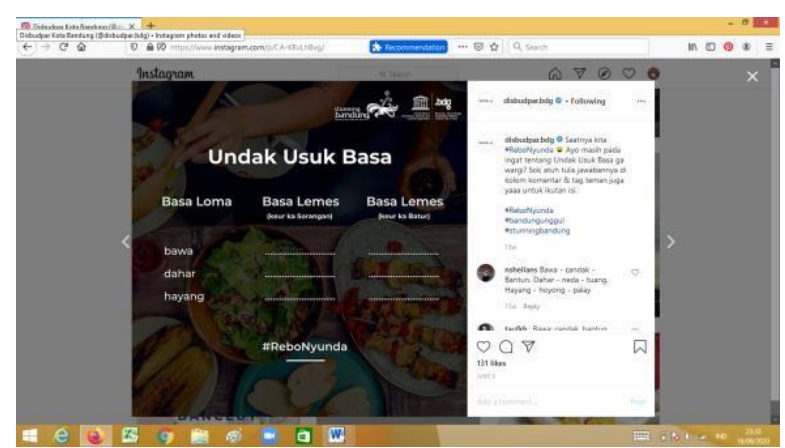

Picture 6. Undak Usuk Basa

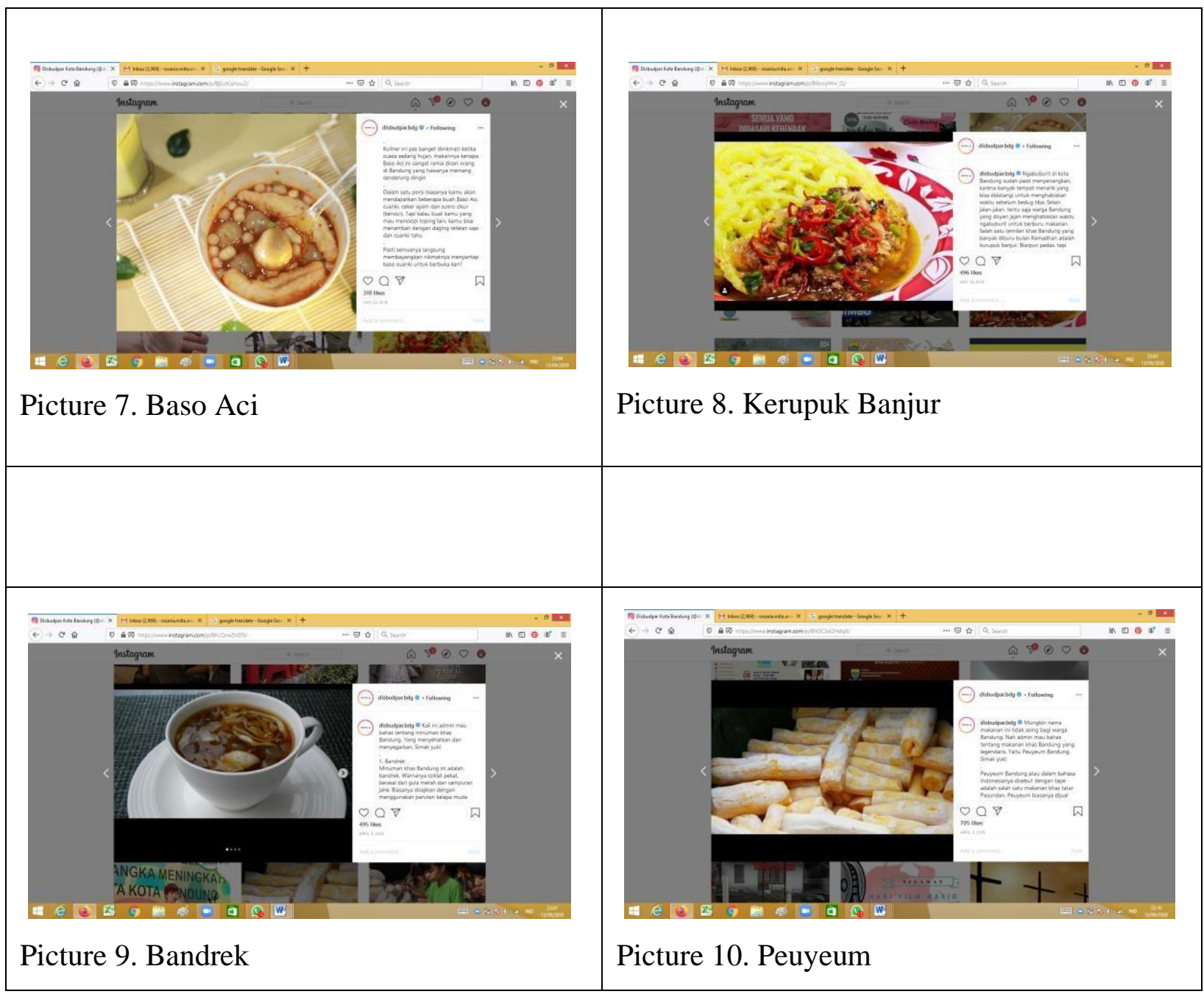

Art is part of the culture of a nation that must be preserved, developed and maintanined. Various cultures are a tourist attraction in an area, including the city of Bandung which has a variety of arts based on traditional Sundanese arts. Information about art is displayed on the Instagram account in a very interesting way. The information displayed in various kinds of arts, for example descriptions of musical instruments such as suling, angklung, tarompet, kendang, 
saron, etc. There is various information about other types of arts such as sisingaan, wayang golek, types of Jaipong dances, Merak, and others. The choice of diction to show a detailed description of a musical instrument such as its parts and how to play it, 'Suling is a type of wind instrument made of bamboo with 4,5, and 6 holes.

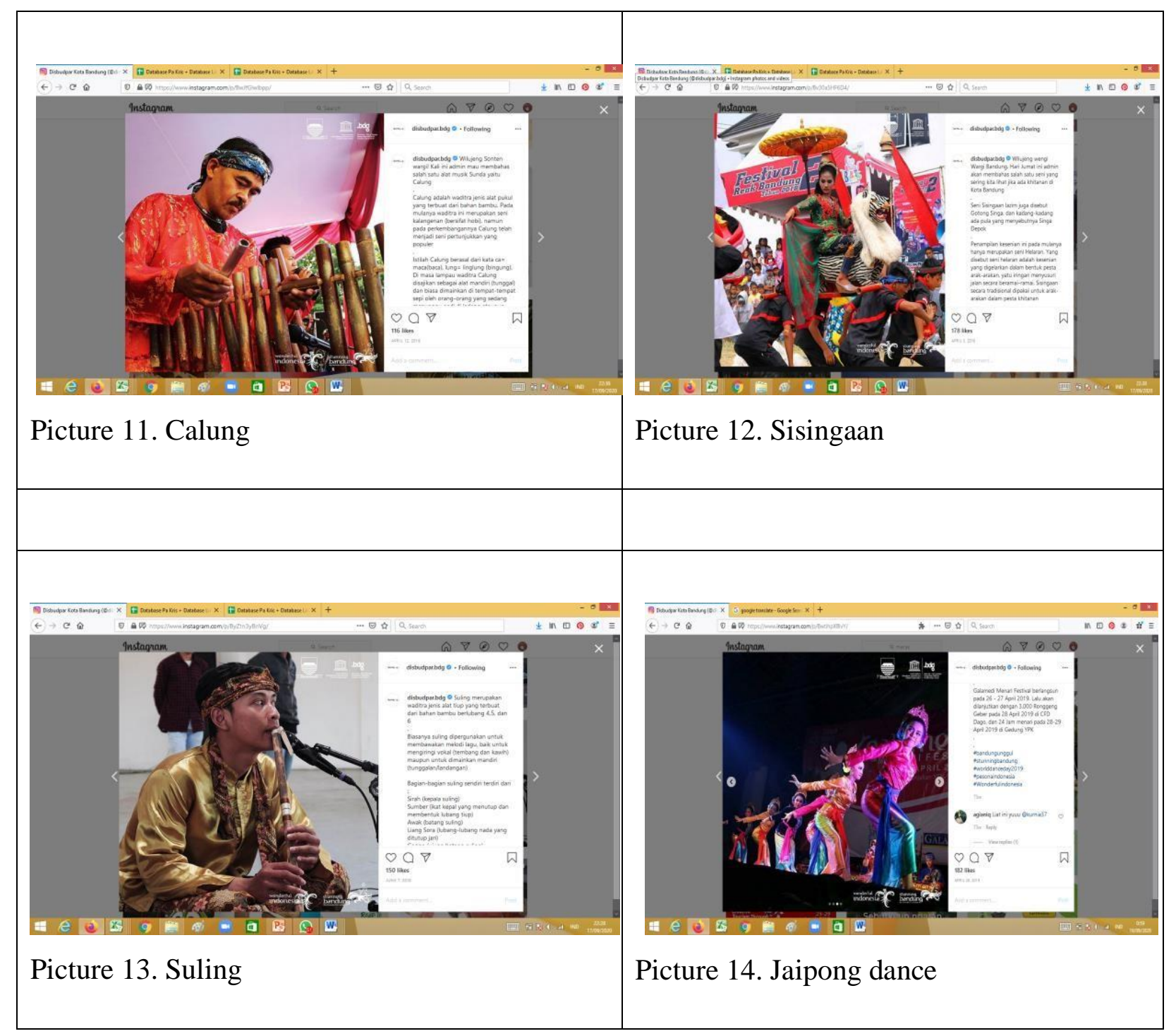

Various tourist attractions in the city of Bandung are one of the strengths of tourism. These tourist attractions consist of natural and artificial tourism. On its page, this Instagram account provides detailed descriptions of tourist attractions. The words used can attract readers to come to these places or even promote to other tourists to visit. Some of the tourist attractions include Taman Hutan Raya Ir. Djuanda (Forest Park), Bandung Zoo, Bandung City Square, Cikapundung Terrace, Traffic Park, etc. Some choices of words to attract tourists include, 'cheap entertainment places, tourist destinations in Bandung that are most visited by tourists, 
Prosiding The 1st National Conference on Applied Business, Education, \& Technology (NCABET)"

Unversitas Bina Bangsa 2021

DOI Article : 10.46306/ncabet.v1i1.56

have quite a large collection of protected animals, family tourist destinations, educational locations and research, forest view with river flow'. For the description of a traffic park, a choice of words is used as in the sentence 'the park whose area of about 3.5 hectares has a variety of children's recreational facilities ranging from a mini train, a mini bicycle arena, an amusement stage, a fun game train, a playground, a children's pool, and many other means'. Not only a place for recreation, this park also presents Traffic Safety Education (PKLL) for children under 13 years of age. The facilities provided include the provision of Camejasa material (How to Cross the Road to Be Safe), mini roads with traffic signs and traffic sign billboards'. Detailed descriptions like this provide an attraction for tourists to visit.

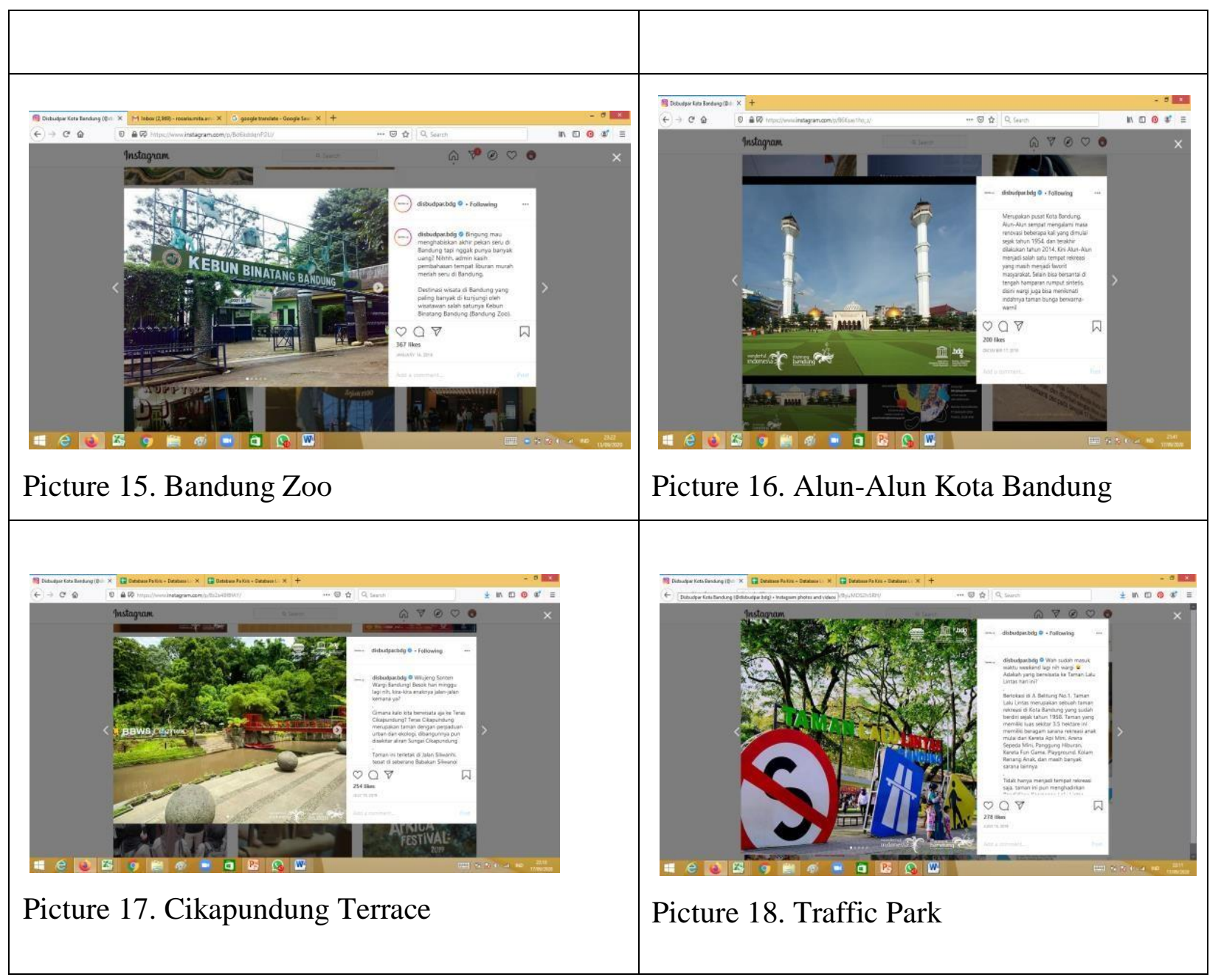

\section{CONCLUSION AND RECOMENDATION}

Cultural diversity is one of the nation's wealth that can be a tourist attraction in an area. The city of Bandung as the capital city of West Java Province has the potential and allure of tourism so that it can attract tourists to come. Cultural diversity and tourism are promoted and informed through social media, instagram account @ disbudpar.bdg. Various potentials and 
cultural attractions are displayed in visual images and captivating narratives. Topics that are displayed such as tourist attractions, art attractions, the use of Sundanese language, culinary tours, etc. show the various cultures and arts from the city of Bandung. The choice of diction through the choice of using verbs, adjectives, and nouns in sentences is a linguistic marker that also shows the diversity of culture and tourism in Bandung.

The use of language in the feeds of instagram account shows how language functions important roles in promoting all programs created by the government. It can create more impacts from the readers that they can share to others and in final goals, it can give impact to the number of visitors to Bandung city. The increasing number of visitors produces extended effect to economic, social, education field and also society.

\section{ACKNOWLEDGEMENT}

The author would like to thank Allah SWT who has given grace and ability so that this research can be completed properly. The author would also like to express his deepest gratitude to the NCBET Committee Team for initiating this very useful event.

\section{REFERENCES}

Amalia, Rosaria Mita. (2017). Globalization of Local Cuisine in West Java: An Attempt to Introduce and Preserve the Cuisine through Cultural Diplomacy. 7th International Conference on Language, Education, and Innovation. 109-115. http://icsai.org/procarch/7iclei/7iclei-068.pdf.

Amalia, Rosaria Mita., Sidik, Inu Isnaeni., Darmayanti, Nani. (2020) Preservation of Sundanese Ethnic Culture by Young Generation in the Era of Globalization. International Journal of

Psychosocial Rehabilitation, 24 (6), 14406-14412. https://www.psychosocial.com/article/PR261382/30917/

Brown, G., \& Yule, G. (2012). Discourse analysis. Cambridge: Cambridge University Press. Creswell, John, W. (2012). Educational research: planning, conducting, and evaluating quantitative and qualitative research. University of Nebraska-Lincoln.

Eriyanto. (2001). Analisis Wacana: Pengantar Analisis Teks Media. (Yogyakarta, LKIS)

Fairclough, N. (2001) Language and Power. (London, Longman).

Fairclough, N. (1995) Critical Discourse Analysis. (London, Longman). 
Prosiding The 1st National Conference on Applied Business, Education, \& Technology (NCABET)", Unversitas Bina Bangsa 2021

DOI Article : 10.46306/ncabet.v1i1.56

Fatanti, Megasari Noer., Suyadnya, Wayan (2015). Beyond User Gaze: How Instagram Creates Tourism Destination Brand? Procedia - Social and Behavioral Sciences. 211 Pages 1089-1095.

https://www.sciencedirect.com/science/article/pii/S1877042815054853

Hanan, H. \& Putit, N. (2014). Express marketing of tourism destination using Instagram in social media networking. In Norzuwana Sumarjan, Mohd Salehudin Mohd Zahari, Salled Mohd Radzi,

Zurinawati Mohi, Mohd Hafiz Mohd hanafiah, Mohd Faeez Saiful Bakhtiar \& Atinah

Zainal (Eds.), Hospitality and Tourism: Synergizing creativity and innovation in research (pp. $471-$

474).

$$
\text { Croydon, }
$$

Great

Britain:

Taylor

$\&$

Francis

Group.

https://books.google.co.id/books?hl=en\&lr=\&id=KDQTAgAAQBAJ\&oi=fnd\&pg=PA471\&

$\underline{\mathrm{dq}}=$

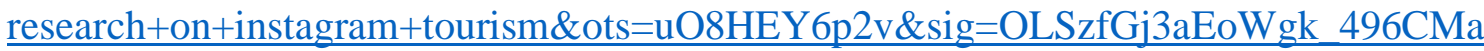
j9n79M

\&redir_esc $=\mathrm{y} \# \mathrm{v}=$ onepage $\& \mathrm{q}=$ research $\% 20 \mathrm{on} \% 20$ instagram\%20tourism $\& \mathrm{f}=$ false

Jogersen, Marianne., \& Phili[s, Louise. (2002). Discourse Analysis as Theory and Method.

(London: Sage Publications Ltd.)

Gee, J., \& Handford, M. (2012). The Routledge handbook of discourse analysis.

Parsons, Hannah. (2017). Does Social Media Influence an Individual's Decision to Visit Tourist Destinantion? Using a Case Study of Instagram. Dissertation. Cardiff Metropolitan University. https://repository.cardiffmet.ac.uk/handle/10369/8710.

Sobarna, Cece., Gugun, Gunardi., Wahya. (2018). Toponimi Nama Tempat Berbahasa Sunda di Kabupaten Banyumas. Panggung Jurnal Seni Budaya. 28 (2), 147-160. https://jurnal.isbi.ac.id/index.php/panggung/article/view/426/pdf

Yu, Chung-En., Sun, Runsheng. (2019). The role of Instagram in the UNESCO's creative city of gastronomy: A case study of Macau. Tourism Management, 75 Pages 257-268.

https://www.sciencedirect.com/science/article/abs/pii/S0261517719301116 